Article

\title{
Analysis of Angiotensin Converting Enzyme, Endothelial Nitric Oxide Synthase \& Serotonin Gene Polymorphisms among Atrial Septal Defect Subjects with and without Pulmonary Arterial Hypertension
}

\author{
Nur Ilyana Jaafar ${ }^{1}$, Ramachandran Vasudevan ${ }^{2, *}$, Patimah Ismail ${ }^{1, *}$, Ahmad Fazli Abdul Aziz ${ }^{3}$, \\ Nur Afiqah Mohamad ${ }^{2}{ }^{(D}$, Geetha Kandavello ${ }^{4}$, Raja Nurzatul Effah Raja Adnan ${ }^{2}$ and \\ Vinod Balasubramaniam ${ }^{5}$ \\ 1 Department of Biomedical Sciences, Faculty of Medicine and Health Sciences, Universiti Putra Malaysia, \\ Serdang 43400, Malaysia; elle.ilyana@gmail.com \\ 2 Malaysian Research Institute on Ageing, Universiti Putra Malaysia, Serdang 43400, Malaysia; \\ nur_iqa87@yahoo.com (N.A.M.); r_zatulefa@upm.edu.my (R.N.E.R.A.) \\ 3 Department of Medicine, Faculty of Medicine and Health Sciences, Universiti Putra Malaysia, \\ Serdang 43400, Malaysia; afazli@upm.edu.my \\ 4 Department of Pediatric Clinic, National Heart Institute, Jalan Tun Razak, Kuala Lumpur 50400, Malaysia; \\ geetha@ijn.com.my \\ 5 Jeffrey Cheah School of Medicine and Health Sciences, Monash University Malaysia, Bandar Sunway 47500, \\ Malaysia; vinod.balasubramaniam@monash.edu \\ * Correspondence: vasuphd@gmail.com (R.V.); patimah@upm.edu.my (P.I.); \\ Tel.: +60-7-254-6430 (R.V.); +60-10-205-5338 (P.I.)
}

Received: 10 July 2018; Accepted: 17 September 2018; Published: 18 September 2018

check for updates

\begin{abstract}
Genetic polymorphisms are variations in DNA sequences which can influence either disease susceptibility, severity, or prognosis. Pulmonary arterial hypertension (PAH) is one of the complications that occurs in certain patients who have atrial septal defect (ASD). This study seeks to determine the association of gene polymorphisms with the pathogenesis of PAH in ASD patients. This study was conducted on 30 ASD patients with PAH, and 50 ASD patients who were not diagnosed with PAH. All respondents were Malay. Patients were selected based on stringent inclusion and exclusion criteria. Molecular analyses were done to detect the genetic polymorphisms of angiotensin converting enzyme (ACE I/D), serotonin transporter (5-HTTLPR), endothelial nitric oxide synthase (eNOS) G894T, and eNOS $4 b / 4 a$. The genotypes of these genetic polymorphisms were determined using conventional PCR and PCR-RFLP methods. The PCR products were analysed using agarose gel electrophoresis. Statistical analysis was done using SPSS Version 22. Clinical characteristics, such as the diameter of ASD, mean arterial pressure (MAP), and mean pulmonary artery pressure (mPAP) differed significantly $(p<0.05)$. Based on the statistical analysis, ACE I/D, eNOS G894T, and eNOS $4 b / 4 a$ do not contribute to the progression of PAH amongst ASD patients $(p>0.05)$. However, the L allele of the 5-HTTLPR gene polymorphism may have an affect on the development of PAH in ASD patients $(p<0.05)$.
\end{abstract}

Keywords: pulmonary artery hypertension; atrial septal defect; genetic polymorphisms

\section{Introduction}

Atrial septal defect (ASD) is a congenital heart defect caused by the presence of an interatrial communication. ASD is usually asymptomatic in children, but in adults, it may be complicated by pulmonary arterial hypertension (PAH). Since PAH patients do not show obvious symptoms at the 
early stage, there may be delayed diagnosis and treatment [1]. PAH, a disease that affects small pulmonary arteries, is characterised by an increase in the pressure of pulmonary artery and pulmonary vessels' resistance, which can lead to death due to right ventricular failure [2]. The normal blood pressure of a pulmonary artery at rest is usually around $8 \mathrm{mmHg}$ to $20 \mathrm{mmHg}$, but in pulmonary arterial hypertensive individuals, the mean pulmonary arterial pressure at rest is $>25 \mathrm{mmHg}$ with normal pulmonary capillary wedge pressure [3]. In most cases, ASD causes left-to-right shunts [4]. The direction and magnitude of the shunting strongly depends on the size of the defect and the relative compliance of the left and right that can change over time [2]. The incidence of PAH is around 2 cases per a million population per year, and can affect individuals at any age, but is most common among adults between 36 to 50 years of age [1]. Patients with ASD are usually asymptomatic and tend to develop PAH after turning 30. However, in some patients, the onset of PAH is noted earlier, and even in small ASD with insignificant left to right shunts. The reason remains unclear. It is believed that in this group of patients, the pathophysiology of PAH is more similar to those with idiopathic PAH.

There are several genes being hypothesised to be involved in PAH, such as serotonin (5-HT), endothelial nitric oxide synthase (eNOS), and angiotensin converting enzyme (ACE I/D) $[5,6]$. A conducted meta-analysis showed a significant association between serotonin transporter (SERT) polymorphism with idiopathic pulmonary hypertension [7], but there is a lack of study on SERT polymorphism with PAH in ASD. A functional gene polymorphism has been identified at the promoter region of the 5-HT gene, a $44 \mathrm{bp}$ insertion/deletion polymorphism (5-HTTLPR) [8]. A study in pediatric patients of idiopathic PAH shows the presence of homozygous L genotype in $90 \%$ of the patients, suggesting the role of 5-HTT in the development of pulmonary hypertension both in children and adults [9].

Nitric oxide synthase is one of the candidate genes involved in PAH. The NOS3 or eNOS gene that encodes eNOS is expressed by vascular endothelial cells. Variations in the gene will alter nitric oxide (NO) synthesis. Polymorphisms of the eNOS gene have been studied in several populations in relation to IPAH $[10,11]$ and cardiovascular disorders [12].

The role of $A C E$ insertion/deletion (I/D) polymorphism on the development of PAH will be investigated in this study as well. The ACE gene, a major component in renin angiotensin aldosterone system, has been implicated in the pathogenesis of cardiovascular disease [13] and essential hypertension [14]. I/D polymorphism of $A C E$ gene is one of the most common polymorphisms being studied $[15,16]$. The risk of developing coronary artery disease, myocardial infarction, or left ventricular hypertrophy increase with the presence of the ACE DD genotype $[17,18]$. Therefore, it has been postulated that the $A C E$ genotype plays a role in PAH progression by modulating the expression of the ACE gene [19].

Since genetic diversity exists among different ethnic populations, and taking into account the fact that the association in one population could not be extrapolated to another, this study only involves Malay patients. In Malaysia, there is lack of data on the association between genetic polymorphisms with PAH and ASD. This stimulated us to study genetic polymorphisms in relation to the early progression of PAH associated with ASD.

\section{Materials and Methods}

This study comprises of 30 ASD subjects with pulmonary arterial hypertension (cases), and 50 ASD subjects without pulmonary arterial hypertension (controls). The subjects were recruited from the Pediatric Clinic of the National Heart Institute. Sample size was calculated by aiming at $80 \%$ statistical power. Prior to recruiting the subjects, ethical approval was obtained from the Ethic Institutional Review Board of Universiti Putra Malaysia (UPM) and the Ethics Committee of the National Heart Institute. The work was carried out in accordance with The Code of Ethics of The World Medical Association (Declaration of Helsinki) for experiments on humans. Consent was obtained from all subjects before recruiting them, and the socio-demographic and medical history of each subject was recorded. Subjects were diagnosed with established PAH by right heart catherisation and with 
secundum Atrial Septal Defect, with no other cardiac anomaly. The next criteria are subjects with mean pulmonary arterial pressure $>50 \%$ mean systemic pressure, and mean pulmonary capillary wedge pressure $<2 \mathrm{kPa}(15 \mathrm{mmHg})$. Patients who are genotypically diagnosed with Down Syndrome with abnormally accelerated $\mathrm{PAH}$ or PAH related to other etiologies and patients suffering from other than secundum ASD were excluded from the study.

\subsection{Genetic Analysis}

A total of $4 \mathrm{~mL}$ of blood was collected from subjects' peripheral blood leukocytes into an EDTA tube (Becton Dickinson, East Rutherford, NJ, USA) by a qualified phlebotomist. Plasma was separated from the blood by centrifugation and stored at $-20^{\circ} \mathrm{C}$ for further analysis. Genomic DNA from peripheral blood was isolated by using the QIAamp Blood DNA Mini Kit (QIAGEN, Hilden, Germany). The purity of extracted DNA was checked by using a Biophotometer (Eppendorf, Hamburg, Germany). Each gene polymorphism underwent PCR by using their respective primers and specific reaction conditions (Table 1).

Table 1. Primers and PCR product for each gene polymorphisms.

\begin{tabular}{|c|c|c|c|c|c|}
\hline $\begin{array}{c}\text { Gene } \\
\text { Polymorphisms }\end{array}$ & Primers & \multicolumn{2}{|c|}{ PCR Cycling Conditions } & \multirow{2}{*}{$\begin{array}{c}\text { PCR } \\
\text { Products (bp) } \\
\\
190-\text { DD } \\
490-\text { II } \\
40 \& 190-\text { ID }\end{array}$} & \multirow{2}{*}{$\begin{array}{c}\text { References } \\
{[20]}\end{array}$} \\
\hline$A C E \mathrm{I} / \mathrm{D}(\mathrm{rs} 4340)$ & $\begin{array}{c}\text { Forward: 5'-CTG GAG ACC ACT } \\
\text { CCC ATC CTT TCT-3 } 3^{\prime} \\
\text { Reverse: } 5^{\prime} \text {-GAT GTG GCC ATC } \\
\text { ACA TTC GTC ACG -AT-3' }\end{array}$ & $\begin{array}{c}\text { Denaturation } \\
\text { Annealing } \\
\text { Extension } \\
\text { Final Extension } \\
\text { Number of Cycles }\end{array}$ & $\begin{array}{l}95^{\circ} \mathrm{C}, 1 \mathrm{~min} \\
58^{\circ} \mathrm{C}, 2 \mathrm{~min} \\
72^{\circ} \mathrm{C}, 1 \mathrm{~min} \\
72^{\circ} \mathrm{C}, 2 \mathrm{~min} \\
30 \text { cycles }\end{array}$ & & \\
\hline$A C E$ mistyping & $\begin{array}{c}\text { Forward: } 5^{\prime}-\mathrm{TGG} \text { GAC CAC AGC } \\
\text { GCC CGC CAC TAC-3' } \\
\text { Reverse: } 5^{\prime} \text {-TCG CCA GCC CTC } \\
\text { CCA TGC CCA TAA-3' }\end{array}$ & $\begin{array}{c}\text { Denaturation } \\
\text { Annealing } \\
\text { Extension } \\
\text { Final Extension } \\
\text { Number of Cycles }\end{array}$ & $\begin{array}{c}94^{\circ} \mathrm{C}, 30 \mathrm{~s} \\
67^{\circ} \mathrm{C}, 45 \mathrm{~s} \\
72^{\circ} \mathrm{C}, 2 \mathrm{~min} \\
72^{\circ} \mathrm{C}, 2 \mathrm{~min} \\
30 \text { cycles }\end{array}$ & $\begin{array}{c}\text { 353-I allele } \\
\text { no band-DD }\end{array}$ & [21] \\
\hline $\begin{array}{c}\text { eNOS G894T } \\
(\mathrm{rs} 1799983)\end{array}$ & $\begin{array}{c}\text { Forward: 5'-AAG GCA GGA } \\
\text { GAC AGT GGA TGG A-3' } \\
\text { Reverse: 5'-CCC AGT CAA TCC } \\
\text { CTT TGG TGC TCA-3' }\end{array}$ & $\begin{array}{c}\text { Denaturation } \\
\text { Annealing } \\
\text { Extension } \\
\text { Final Extension } \\
\text { Number of Cycles }\end{array}$ & $\begin{array}{c}94^{\circ} \mathrm{C}, 30 \mathrm{~s} \\
62.8^{\circ} \mathrm{C}, 30 \mathrm{~s} \\
72^{\circ} \mathrm{C}, 2 \mathrm{~min} \\
72^{\circ} \mathrm{C}, 5 \mathrm{~min} \\
35 \mathrm{cycles}\end{array}$ & 248 & [22] \\
\hline$e N O S 4 b / 4 a$ & $\begin{array}{c}\text { Forward: 5'-AGG CCC TAT GGT } \\
\text { AGT GCC TTT-3' } \\
\text { Reverse: } 5^{\prime} \text {-TCT CTT AGT GCT } \\
\text { GTG GTC AC- } 3^{\prime}\end{array}$ & $\begin{array}{c}\text { Denaturation } \\
\text { Annealing } \\
\text { Extension } \\
\text { Final Extension } \\
\text { Number of Cycles }\end{array}$ & $\begin{array}{l}94^{\circ} \mathrm{C}, 1 \mathrm{~min} \\
56^{\circ} \mathrm{C}, 1 \mathrm{~min} \\
72^{\circ} \mathrm{C}, 2 \mathrm{~min} \\
72^{\circ} \mathrm{C}, 7 \mathrm{~min} \\
35 \text { cycles }\end{array}$ & $\begin{array}{c}393-4 a / a \\
420-4 b / b \\
393 \& 420-4 a / b\end{array}$ & [23] \\
\hline $\begin{array}{l}\text { 5-HTTLPR } \\
\text { (rs25531) }\end{array}$ & $\begin{array}{c}\text { Forward: 5'-GGC GTT GCC GCT } \\
\text { CTG AAT GC-3'3 } \\
\text { Reverse: } 5^{\prime} \text {-GGC GTT GCC GCT } \\
\text { CTG AAT GC-3' }\end{array}$ & $\begin{array}{c}\text { Denaturation } \\
\text { Annealing } \\
\text { Extension } \\
\text { Final Extension } \\
\text { Number of Cycles }\end{array}$ & $\begin{array}{c}94^{\circ} \mathrm{C}, 30 \mathrm{~s} \\
61^{\circ} \mathrm{C}, 30 \mathrm{~s} \\
72^{\circ} \mathrm{C}, 1 \mathrm{~min} \\
72^{\circ} \mathrm{C}, 10 \mathrm{~min} \\
35 \text { cycles }\end{array}$ & $\begin{array}{c}528-\mathrm{LL} \\
484 \text {-SS } \\
484 \& 528-\mathrm{LS}\end{array}$ & [24] \\
\hline
\end{tabular}

The PCR reactions were done by using a G-Storm GS1 Thermal Cyclers (Somertone Biotechnology Center, Somerset, UK). The PCR products were then kept at $-20{ }^{\circ} \mathrm{C}$ for further analysis. The PCR products were determined by using agarose gel electrophoresis, and visualised under UV light. The results were validated by choosing $20 \%$ of samples at random, and a similar analysis was again carried out to confirm the genotyping results. Identical results were obtained when the genotyping was performed on two separate occasions.

\subsection{Statistical Analysis}

Clinical characteristics of all the subjects were expressed as mean \pm SD. The student's t-test and chi-square test were used to analyse the variables. The frequencies of alleles were estimated by using the allele counting method and Hardy-Weinberg equilibrium assessment. A one-way ANOVA test was used to compare the group means. All statistical analyses were performed by using SPSS version 21.0 (SPSS Inc., Chicago, IL, USA); $p<0.05$ was considered to be statistically significant. 


\section{Results}

In this study, 80 ASD patients of Malay ethnicity were sampled. The control group, which are ASD patients without PAH, comprised of 50 (62.5\%) samples, whereas $30(37.5 \%)$ were ASD patients with PAH. A majority of the ASD patients with PAH were female (93.3\%). Whereas for those diagnosed with ASD without PAH, 88\% were females. Table 2 tabulates the clinical characteristics of subjects in both groups with respect to age, age at diagnosis, size of ASD, mean arterial pressure (MAP), and mPAP with $p<0.05$.

Table 2. Clinical characteristics of PAH patients and control subjects.

\begin{tabular}{cccc}
\hline Parameter & $\begin{array}{c}\text { Case Subjects } \\
\text { (ASD with PAH) }\end{array}$ & $\begin{array}{c}\text { Control Subjects } \\
\text { (ASD without PAH) }\end{array}$ & $p$ Value \\
\hline Gender, M/F & $2 / 28$ & $6 / 44$ & - \\
Age & $33.33 \pm 9.316$ & $37.50 \pm 14.971$ & 0.174 \\
Age diagnosed & $28.97 \pm 8.838$ & $32.80 \pm 14.474$ & 0.194 \\
Diameter of defects (cm) & $3.19 \pm 4.018$ & $1.88 \pm 0.852$ & $* 0.028$ \\
MAP (mmHg) & $89.30 \pm 12.438$ & $78.82 \pm 18.169$ & $* 0.007$ \\
mPAP (mmHg) & $58.88 \pm 14.53$ & $22.04 \pm 10.517$ & $* 0.000$ \\
\hline
\end{tabular}

$\mathrm{PAH}$, pulmonary arterial hypertension; ASD, atrial septal defect; MAP, mean arterial pressure; mPAP, mean pulmonary arterial pressure. * Significant $p<0.05$. Values shown are mean $\pm \mathrm{SD}$.

The mean age for the control subjects was higher than that of the case subjects. There was no significant difference observed for age and age patients diagnosed with ASD. However, patients with PAH were diagnosed to have ASD earlier than ASD patients who had not developed PAH. There was a significant difference found in the diameter of defects, MAP and mPAP. The size of ASD was found to be bigger in patients with PAH. Figure 1 shows the PCR products of each gene polymorphism, and Table 3 demonstrates the genotypic and allelic distributions of ACE I/D, G894T and $4 b / 4 a$ gene polymorphism of the eNOS gene and the 5-HTTLPR gene polymorphism of the PAH and non-PAH groups.

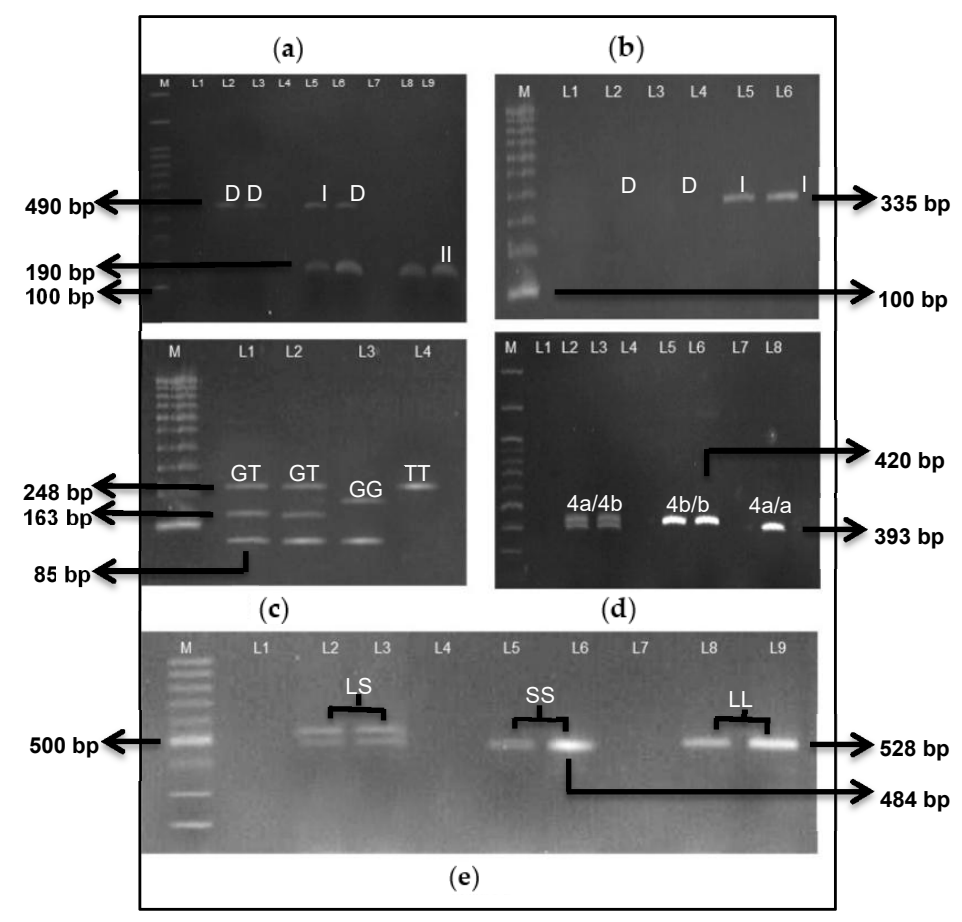

Figure 1. (a) Amplification of ACE I/D in $2 \%$ agarose gel. DD genotype was denoted by $490 \mathrm{bp}$ band (Lane 2 \& 3) and II genotype was shown by 190 bp band (Lane 8 \& 9) whereas ID genotype showed 
both $190 \mathrm{bp}$ and $490 \mathrm{bp}$ bands (Lane 5 \& 6). (b) Mistyping of ACE I/D. I allele showed 335 bp band (Lane 5 \& 6) whereas DD genotype was proven by the absence of any band (Lane $2 \& 3$ ). (c) Restriction fragments in $4 \%$ agarose gel. Heterozygous type (GT genotype) showed three bands consists of $85 \mathrm{bp}$, $163 \mathrm{bp}$ and $248 \mathrm{bp}$ (Lane 1 \& 2). GG genotype was showed by $85 \mathrm{bp}$ and $163 \mathrm{bp}$ bands (Lane 3). Lane 4 shows the undigested 248 bp band, which was TT genotype (mutant). (d) PCR product of eNOS $4 b / 4 a$ amplification in $2 \%$ agarose. Heterozygous sample $(4 \mathrm{a} / \mathrm{b})$ was shown by both $393 \mathrm{bp}$ and $420 \mathrm{bp}$ bands (Lane $2 \& 3$ ). Wild type (4b/b) was shown by a $420 \mathrm{bp}$ band (Lane $5 \& 6$ ). $393 \mathrm{bp}$ band indicated a mutant (4a/a) sample (Lane 8). (e) Amplification of 5-HTTLPR in 1.5\% agarose gel. A heterozygous type (LS genotype) showed both $484 \mathrm{bp}$ and $528 \mathrm{bp}$ bands (Lane $2 \& 3$ ). SS genotype was indicated by $484 \mathrm{~b}$ p band (Lane $5 \&$ 6) whereas LL genotype was shown by a 528 bp band (Lane 8 \& 9). M: 100-bp marker.

Table 3. Distribution of genotypes and allele frequencies of each gene polymorphisms between PAH patients and control subjects.

\begin{tabular}{|c|c|c|c|c|c|}
\hline \multicolumn{2}{|c|}{ Gene Polymorphism } & $\begin{array}{l}\text { PAH Patients } \\
(\mathrm{n}=30) \\
\mathrm{n}(\%)\end{array}$ & $\begin{array}{l}\text { Control Subjects } \\
\qquad \begin{array}{c}(\mathrm{n}=50) \\
\mathrm{n}(\%)\end{array}\end{array}$ & $p$ Value & $\begin{array}{c}\text { Odds Ratio } \\
\text { (95\% Confidence Interval) }\end{array}$ \\
\hline \multirow{7}{*}{$A C E I / D$} & Genotypes & & & & \multirow{7}{*}{$\begin{array}{c}0.68 \\
(0.33-1.41)\end{array}$} \\
\hline & II & $17(56.67 \%)$ & $22(44 \%)$ & \multirow{3}{*}{0.53} & \\
\hline & ID & $12(40 \%)$ & $25(50 \%)$ & & \\
\hline & DD & $1(3.33 \%)$ & $3(6 \%)$ & & \\
\hline & \multicolumn{4}{|l|}{ Alleles } & \\
\hline & I & $46(76.67 \%)$ & $69(69 \%)$ & \multirow{2}{*}{0.30} & \\
\hline & $\mathrm{D}$ & $14(23.33 \%)$ & $31(31 \%)$ & & \\
\hline \multirow{7}{*}{ eNOS G894T } & Genotypes & & & & \\
\hline & GG & $0(0 \%)$ & $1(2 \%)$ & \multirow{3}{*}{0.63} & \multirow{6}{*}{$\begin{array}{c}0.98 \\
(0.51-1.85)\end{array}$} \\
\hline & GT & $29(96.67 \%)$ & 47 (94\%) & & \\
\hline & $\mathrm{TT}$ & $1(3.33 \%)$ & $2(4 \%)$ & & \\
\hline & Alleles & & & & \\
\hline & $\mathrm{G}$ & $29(48.33 \%)$ & $49(49 \%)$ & \multirow{2}{*}{0.94} & \\
\hline & $\mathrm{T}$ & $31(51.67 \%)$ & $51(51 \%)$ & & \\
\hline \multirow{7}{*}{$e N O S 4 b / 4 a$} & Genotypes & & & & \multirow{7}{*}{$\begin{array}{c}1.217 \\
(0.56-2.64)\end{array}$} \\
\hline & $\begin{array}{c}4 \mathrm{~b} / \mathrm{b} \\
\text { (wild type) }\end{array}$ & $21(70 \%)$ & $35(70 \%)$ & \multirow{3}{*}{0.57} & \\
\hline & $4 a / a$ (mutant) & $5(16.7 \%)$ & $5(10 \%)$ & & \\
\hline & $4 \mathrm{a} / \mathrm{b}$ & $4(13.3 \%)$ & $10(20 \%)$ & & \\
\hline & \multicolumn{4}{|l|}{ Alleles } & \\
\hline & a & $14(23.33 \%)$ & $20(20 \%)$ & \multirow{2}{*}{0.62} & \\
\hline & $\mathrm{b}$ & $46(76.67 \%)$ & $80(80 \%)$ & & \\
\hline \multirow{7}{*}{ 5-HTTLPR } & Genotypes & & & & \multirow{7}{*}{$\begin{array}{c}0.43 \\
(0.22-0.82)\end{array}$} \\
\hline & SS & $6(20 \%)$ & $23(46 \%)$ & \multirow{3}{*}{0.06} & \\
\hline & LL & $12(40 \%)$ & $12(24 \%)$ & & \\
\hline & LS & $12(40 \%)$ & $15(30 \%)$ & & \\
\hline & \multicolumn{4}{|l|}{ Alleles } & \\
\hline & S & $24(40 \%)$ & $61(61 \%)$ & \multirow{2}{*}{ * 0.01} & \\
\hline & $\mathrm{L}$ & $36(60 \%)$ & $39(39 \%)$ & & \\
\hline
\end{tabular}

* Value $(p<0.05)$ was obtained using chi-square test as compared with controls. Data are reported as number of subjects, with percent in parentheses.

There was no significant association found between the ACE I/D and both eNOS G894T and $e N O S 4 b / 4 a$ gene polymorphisms with the ASD subjects $(p<0.05)$. However, there is an association between the L allele of 5-HTTLPR gene polymorphism with PAH among ASD patients $(p<0.05)$. A multivariate test (General Linear Model) was performed to identify the confounding factor for all the genetic polymorphisms, to compare the associations between genotypes and clinical parameters (Table 4). In this study, the clinical parameters analysed are age, diameter of defects, MAP, and mPAP. There were no significant differences found between the genotypes of all the gene polymorphisms of the genes studied and the risk factors in both groups. 
Table 4. Distribution between polymorphisms and clinical characteristics of the subjects.

\begin{tabular}{|c|c|c|c|c|c|c|c|c|}
\hline \multirow[t]{2}{*}{ Gene Polymorphism } & \multicolumn{4}{|c|}{ ASD with PAH (Case) } & \multicolumn{4}{|c|}{ ASD without PAH (Control) } \\
\hline & Age * & Size of Defect * & $\begin{array}{c}\text { MAP * } \\
(\mathbf{m m H g})\end{array}$ & $\begin{array}{l}\text { mPAP * } \\
(\mathrm{mmHg})\end{array}$ & Age * & Size of Defect * & $\begin{array}{c}\text { MAP * } \\
(\mathbf{m m H g})\end{array}$ & $\begin{array}{l}\text { mPAP }{ }^{*} \\
(\mathrm{mmHg})\end{array}$ \\
\hline \multicolumn{9}{|l|}{$A C E I / D$} \\
\hline II & $32.71 \pm 9.51$ & $2.59 \pm 0.88$ & $90.71 \pm 10.51$ & $59.09 \pm 17.53$ & $36.95 \pm 13.54$ & $2.18 \pm 0.77$ & $72.86 \pm 23.51$ & $24.23 \pm 12.59$ \\
\hline ID & $34.42 \pm 9.75$ & $4.29 \pm 6.23$ & $87.25 \pm 15.48$ & $58.92 \pm 10.40$ & $39.64 \pm 16.03$ & $1.66 \pm 0.83$ & $84.20 \pm 10.79$ & $20.64 \pm 8.58$ \\
\hline DD & $31.00 \pm 0.00$ & $0.22 \pm 0.00$ & $90.00 \pm 0.00$ & $55.00 \pm 0.00$ & $23.67 \pm 11.59$ & $1.44 \pm 1.24$ & $77.67 \pm 11.68$ & $17.67 \pm 7.64$ \\
\hline \multicolumn{9}{|l|}{ eNOS G894T } \\
\hline GG & - & - & - & - & $29.00 \pm 0.00$ & $1.96 \pm 0.00$ & $77.00 \pm 0.00$ & $17.00 \pm 0.00$ \\
\hline GT & $32.66 \pm 8.69$ & $3.22 \pm 4.09$ & $89.10 \pm 12.61$ & $58.98 \pm 14.77$ & $38.07 \pm 15.48$ & $1.91 \pm 0.85$ & $78.54 \pm 18.90$ & $35.11 \pm 21.98$ \\
\hline $\mathrm{TT}$ & $53.00 \pm 0.00$ & $2.30 \pm 0.00$ & $95.00 \pm 0.00$ & $56.00 \pm 0.00$ & $31.67 \pm 1.53$ & $1.27 \pm 0.90$ & $83.67 \pm 4.04$ & $35.75 \pm 17.21$ \\
\hline \multicolumn{9}{|l|}{$e N O S 4 b / 4 a$} \\
\hline $4 \mathrm{~b} / \mathrm{b}$ & $35.48 \pm 9.82$ & $3.60 \pm 4.45$ & $89.29 \pm 13.17$ & $58.07 \pm 14.23$ & $38.37 \pm 16.24$ & $1.94 \pm 0.87$ & $78.91 \pm 11.78$ & $21.69 \pm 9.40$ \\
\hline $4 a / b$ & $27.50 \pm 8.43$ & $3.75 \pm 3.59$ & $93.25 \pm 15.15$ & $71.50 \pm 13.48$ & $36.90 \pm 13.34$ & $1.85 \pm 0.82$ & $78.50 \pm 24.29$ & $26.70 \pm 14.47$ \\
\hline $4 a / a$ & $29.00 \pm 3.54$ & $1.05 \pm 1.23$ & $86.20 \pm 7.40$ & $52.20 \pm 12.76$ & $32.60 \pm 8.17$ & $1.47 \pm 0.82$ & $78.70 \pm 5.40$ & $15.20 \pm 4.32$ \\
\hline \multicolumn{9}{|l|}{ 5-HTTLPR } \\
\hline SS & $36.00 \pm 9.80$ & $2.77 \pm 0.77$ & $93.33 \pm 8.60$ & $52.67 \pm 11.38$ & $38.52 \pm 15.73$ & $1.87 \pm 0.87$ & $78.35 \pm 20.18$ & $22.65 \pm 11.27$ \\
\hline LS & $33.50 \pm 10.71$ & $4.57 \pm 6.12$ & $88.08 \pm 11.57$ & $59.08 \pm 17.05$ & $40.13 \pm 14.82$ & $1.98 \pm 0.71$ & $78.87 \pm 19.70$ & $22.20 \pm 10.52$ \\
\hline LL & $31.83 \pm 8.01$ & $2.04 \pm 1.09$ & $88.50 \pm 15.14$ & $61.79 \pm 13.28$ & $32.25 \pm 13.51$ & $1.76 \pm 1.02$ & $79.66 \pm 12.70$ & $20.67 \pm 11.45$ \\
\hline
\end{tabular}

Values are mean \pm SD. ${ }^{*}=$ not significant $(p>0.05)$. 


\section{Discussion}

This study aims to identify the differences between ASD patients without PAH and ASD patients with PAH in terms of genetic makeup, as this may help us have more understanding on the pathophysiology of the disease. Candidate gene analysis enables the identification of the presence of known gene variations of candidate genes (ACE, eNOS and 5-HTTLPR) that may be implicated in the pathogenesis of PAH. Thus, a genotype-phenotype association can be determined, and patients can then be classified into the high-risk group that may develop PAH, so that early therapeutic and preventive measures can be implemented. The findings from this study might give some new insight into the management of ASD patients.

A higher percentage of LL genotypes of 5-HTTLPR with gene polymorphism was noticed in the PAH group. Our findings support the 5-HTT pathway in causing pulmonary vascular remodeling and PAH development by the overexpression of 5-HTT [20,21]. Patients with LL genotypes will express more than double the serotonin mRNA in the pulmonary artery muscle cells [22]. In this present study, we found that the L allele of the 5-HTTLPR gene polymorphism was associated with an increased risk of possible PAH. To the best of our knowledge, this is the first molecular study on our population that investigates the association of the 5-HTTLPR gene polymorphism with PAH in Malay ASD patients. It is in correspondence with studies by Eddahibi et al. (2001) [20] and Willers et al. (2006) [22], which suggested an association between the LL genotype and the risk of developing PH. Although statistical differences were not reached, higher mPAP was observed for the LL genotypes in the PAH group. These findings are in accordance with another study conducted on Spanish [22], Caucasian [23] and Turkish [24] subjects. Other than that, the diameter of defects were found to be larger for the SS and LS genotypes, but the mPAP was higher for the LL genotypes in the PAH group. It is suggested that patients who carry the LL genotype are more severe than those who carry the SS or LS genotype, despite the size of the defect, due to the higher level of mPAP in the LL group. Homozygous L alleles cause the double expression of serotonin in the primary pulmonary artery smooth muscle cells. This in turn leads to vascular smooth muscle hyperplasia and vascular remodeling, that cause an increase in the pulmonary artery pressure [20].

The deletion polymorphism of the $A C E$ gene has been known to cause an increase in angiotensin II, and renin angiotensin system is involved in pulmonary artery remodeling [25]. However, different studies on the ACE DD genotype effect on cardiovascular diseases have produced different results $[24,26]$. Since there was no significant difference found in the $A C E$ genotype distribution and allele frequencies among groups, it can be concluded that $A C E$ gene polymorphisms may not be the risk factor in the development of PAH among Malay ASD patients. The result was similar to a study by Hoeper et al. (2003), in which there were no significant differences in mPAP between cases and control subjects with II, ID or DD genotypes [27].

A greater percentage of the G allele of $e N O S$ G894T polymorphism in the non-PAH group $(70.65 \%)$, rather that in the PAH patients $(48.4 \%)$, was also observed in Toganel's study [28]. In the present study, the incidence of $\mathrm{G}$ allele was almost similar between the control group (49\%) and the AHD cases (48.33\%). Another study by Vadapalli et al. (2010) [10] also showed that no significant difference was observed between idiopathic PAH and the control group. It is assumed that maybe there are gene-gene and gene-environment interactions that play a role in the function of eNOS G894T polymorphism regarding the pathogenesis of PAH in Malays.

In this present study, we found no association between the eNOS $4 b / 4 a$ polymorphism and PAH in Malay ASD patients. The frequency of the "a" allele was higher in patients with PAH $(23.33 \%)$ as compared to those with ASD (20\%). However, these findings do not support past literature, which correlated a lower detection of NO metabolites with the presence of the "a" allele [29]. A higher percentage of the " $b$ " allele was observed among the non-PAH group. This may suggest a protective effect of the " $b$ " allele against PAH. Another study in Romania [28] on PAH among children with congenital heart diseases also gave negative results. The eNOS $4 b / 4 a$ was also found to have no association with PH in COPD patients in both Turkish and Zurich populations [10,24]. 
Table 5 summarises the genotypic and allelic distributions of all the gene polymorphisms of the genes studied on several types of PAH in other populations, with contradictory results. This can be due to confounding factors, such as different ethnicities, or different environment backgrounds which have influences on the genetic makeup.

Table 5. Genotypes and allele frequency distribution.

\begin{tabular}{|c|c|c|c|c|c|c|c|c|c|c|}
\hline \multirow{2}{*}{$\begin{array}{c}\text { Population } \\
A C E I / D\end{array}$} & \multirow[t]{2}{*}{ Disease } & \multirow[t]{2}{*}{ No } & \multicolumn{3}{|c|}{ Genotypes (\%) } & \multicolumn{4}{|c|}{ Allele (\%) } & \multirow[t]{2}{*}{ Study } \\
\hline & & & II & ID & DD & $p$ Value & $\mathbf{I}$ & D & $p$ Value & \\
\hline Malaysia & HPT & 65 & 36.9 & 52.3 & 10.8 & $*$ & 63.08 & 36.92 & $* *$ & [14] \\
\hline USA & $\mathrm{PPH}$ & 60 & 45 & 35 & 20 & $* *$ & - & - & - & [19] \\
\hline Caucasian & COPD & 66 & 22.73 & 46.97 & 30.3 & $*$ & - & - & - & [30] \\
\hline Romania & $\mathrm{PAH}$ & 29 & 6.90 & 58.62 & 34.48 & $*$ & 39.58 & 60.42 & * & [31] \\
\hline German & $\mathrm{PPH}$ & 51 & 9.8 & 58.82 & 31.37 & NS & - & - & - & [27] \\
\hline Iran & CAD & 224 & 12.5 & 38.84 & 48.66 & NS & 31.92 & 68.08 & NS & [32] \\
\hline Malaysia & PAH & 30 & 56.67 & 40.0 & 3.33 & NS & 76.67 & 23.33 & NS & Current study \\
\hline eNOS G894T & & & GG & GT & TT & & G & $\mathrm{T}$ & & \\
\hline Germany & IPAH & 16 & 27 & 53 & 20 & NS & 53 & 47 & NS & [10] \\
\hline India & IPAH & 77 & 50.65 & 41.16 & 51.95 & NS & 72.73 & 27.27 & NS & [11] \\
\hline India & $\mathrm{EH}$ & 226 & 139 & 82 & 5 & $* * *$ & 79.65 & 20.35 & $* * *$ & [33] \\
\hline Malaysia & PAH & 30 & 0 & 96.67 & 3.33 & NS & 48.33 & 51.67 & NS & Current study \\
\hline$e N O S 4 b / 4 a$ & & & $\mathrm{bb}$ & $\mathrm{ab}$ & $\mathrm{Aa}$ & $\mathrm{p}$ & $\mathrm{a}$ & $\mathrm{b}$ & & \\
\hline Germany & IPAH & 16 & 67 & 33 & - & NS & 83 & 17 & NS & [10] \\
\hline Turkey & $\mathrm{PH}$ in COPD & 24 & 83 & 17 & 0 & $*$ & 8.33 & 91.67 & - & [25] \\
\hline Swiss & $\mathrm{PH}$ in COPD & 27 & 63 & 33 & 4 & NS & 20.37 & 79.63 & - & [34] \\
\hline Malaysia & ESRD & 150 & 87.33 & 11.33 & 1.33 & NS & 93 & 7 & NS & [35] \\
\hline Malaysia & PAH & 30 & 70 & 16.67 & 13.33 & NS & 23.33 & 58.78 & NS & Current study \\
\hline 5-HTTLPR & & & SS & LS & LL & $\mathrm{p}$ & S & $\mathrm{L}$ & & \\
\hline Caucasian & IPAH & 11 & 81.82 & 0 & 18.18 & * & 18.18 & 81.82 & - & [9] \\
\hline Germany & $\mathrm{COPD}+\mathrm{PAH}$ & 27 & 18.52 & 59.26 & 22.22 & - & 51.85 & 48.15 & * & [10] \\
\hline Spain & $\mathrm{IPAH}+2^{\circ} \mathrm{PAH}$ & 49 & 26.53 & 28.15 & 20.41 & NS & 46.94 & 53.06 & - & {$[36]$} \\
\hline Chinese & VSD-related $\mathrm{PAH}$ & 140 & 50.71 & 36.43 & 12.86 & $*$ & 31.07 & 68.93 & - & [37] \\
\hline Malaysia & PAH & 30 & 20 & 40 & 40 & NS & 40 & 60 & * & Current study \\
\hline
\end{tabular}

HPT, hypertension; $\mathrm{PPH}$, primary pulmonary hypertension; COPD, cardiac obstructive pulmonary disease; $\mathrm{PAH}$, pulmonary arterial hypertension; $\mathrm{CAD}$, coronary artery disease; $\mathrm{EH}$, essential hypertension; ESRD, end stage renal disease; IPAH, idiopathic pulmonary arterial hypertension; VSD, ventricular septal defect* $(p<0.05),{ }^{* *}(p<0.01)$, $* * *(p<0.001)$, at $5 \%$ level of significance, NS: not significant $(p>0.05)$.

The present study has some limitations. Although our study sample was relatively small as compared to other epidemiological and association studies, the result of this study supports the hypothesis that the L allele of the 5-HTTLPR gene has an association with PAH in ASD subjects. A more extensive study can be done in future with a larger sample size and more stringent inclusion and exclusion criteria to further confirm the hypothesis, and to confirm the association between the gene polymorphism of the ACE, eNOS, and 5-HTTLPR genes. Further investigation is needed to understand the possible role of other polymorphisms of various genes in relation to ASD among the three ethnic races in Malaysia.

\section{Conclusions}

Among all the gene polymorphisms studied in this study, the 5-HTTLPR (rs25531) can be considered as the candidate gene for the early development of PAH among Malay ASD patients.

Author Contributions: Conceptualization, V.R.; Methodology, V.R.; Validation, V.R., A.F.A.A. and G.K.; Formal Analysis, N.I.J.; Investigation, N.I.J.; Resources, V.R., P.I., A.F.A.A. and G.K.; Data Curation, N.I.J.; Writing-Original Draft Preparation, N.I.J. and V.R.; Writing-Review \& Editing, P.I., A.F.A.A., G.K., N.A.M., R.N.E.R.A. and V.B.; Supervision, V.R. and P.I.; Project Administration, V.R.; Funding Acquisition, P.I.

Funding: This research was funded by the Research University Grant Scheme (RUGS), Universiti Putra Malaysia, grant number 911440.

Acknowledgments: We thank all the staffs of the National Heart Institute involved in this study for their continuous support. Last but not least, we also thank all the patients who participate in this study.

Conflicts of Interest: The authors declare no conflict of interest. 


\section{References}

1. Humbert, M.; Sitbon, O.; Chaouat, A.; Bertocchi, M.; Habib, G.; Gressin, V.; Yaici, A.; Weitzenblum, E.; Cordier, J.F.; Chabot, F.; et al. Pulmonary arterial hypertension in france: Results from a national registry. Am. J. Respir. Crit. Care Med. 2006, 173, 1023-1030. [CrossRef] [PubMed]

2. Barst, R.J. Pulmonary hypertension: Past, present and future. Ann. Thorac. Med. 2008, 3, 1-4. [CrossRef] [PubMed]

3. Tedford, R.J.; Mudd, J.O.; Girgis, R.E.; Mathai, S.C.; Zaiman, A.L.; Housten-Harris, T.; Boyce, D.; Kelemen, B.W.; Bacher, A.C.; Shah, A.A.; et al. Right ventricular dysfunction in systemic sclerosis-associated pulmonary arterial hypertension. Circ. Heart Fail. 2013, 6, 953-963. [CrossRef] [PubMed]

4. Mulder, B.J. Changing demographics of pulmonary arterial hypertension in congenital heart disease. Eur. Respir. Rev. 2010, 19, 308-313. [CrossRef] [PubMed]

5. Ibrahim, E.; Kassem, A.; Zakaria, N. The role of the biomarker and the genetic polymorphism of endothelin-1 in pulmonary arterial hypertension among egyptians. Egypt. J. Chest Dis. Tuberc. 2012, 61, 495-500. [CrossRef]

6. Johansen, A.K.; Dean, A.; Morecroft, I.; Hood, K.; Nilsen, M.; Loughlin, L.; Anagnostopoulou, A.; Touyz, R.M.; White, K.; MacLean, M.R. The serotonin transporter promotes a pathological estrogen metabolic pathway in pulmonary hypertension via cytochrome p450 1b1. Pulm. Circ. 2016, 6, 82-92. [CrossRef] [PubMed]

7. Zhang, H.; Xu, M.; Xia, J.; Qin, R.Y. Association between serotonin transporter (sert) gene polymorphism and idiopathic pulmonary arterial hypertension: A meta-analysis and review of the literature. Metab. Clin. Exp. 2013, 62, 1867-1875. [CrossRef] [PubMed]

8. Heils, A.; Teufel, A.; Petri, S.; Stober, G.; Riederer, P.; Bengel, D.; Lesch, K.P. Allelic variation of human serotonin transporter gene expression. J. Neurochem. 1996, 66, 2621-2624. [CrossRef] [PubMed]

9. Vachharajani, A.; Saunders, S. Allelic variation in the serotonin transporter (5HTT) gene contributes to idiopathic pulmonary hypertension in children. Biochem. Biophys. Res. Commun. 2005, 334, 376-379. [CrossRef] [PubMed]

10. Ulrich, S.; Szamalek-Hoegel, J.; Hersberger, M.; Fischler, M.; Garcia, J.S.; Huber, L.C.; Grunig, E.; Janssen, B.; Speich, R. Sequence variants in bmpr2 and genes involved in the serotonin and nitric oxide pathways in idiopathic pulmonary arterial hypertension and chronic thromboembolic pulmonary hypertension: Relation to clinical parameters and comparison with left heart disease. Respir. Int. Rev. Thorac. Dis. 2010, 79, $279-287$.

11. Vadapalli, S.; Rani, H.S.; Sastry, B.; Nallari, P. Endothelin-1 and endothelial nitric oxide polymorphisms in idiopathic pulmonary arterial hypertension. Int. J. Mol. Epidemiol. Genet. 2010, 1, 208-213. [PubMed]

12. Luo, J.Q.; Wen, J.G.; Zhou, H.H.; Chen, X.P.; Zhang, W. Endothelial nitric oxide synthase gene g894t polymorphism and myocardial infarction: A meta-analysis of 34 studies involving 21,068 subjects. PLoS ONE 2014, 9, e87196. [CrossRef] [PubMed]

13. Alvarez, R.; Gonzalez, P.; Batalla, A.; Reguero, J.R.; Iglesias-Cubero, G.; Hevia, S.; Cortina, A.; Merino, E.; Gonzalez, I.; Alvarez, V.; et al. Association between the nos3 (-786 t/c) and the ace (i/d) DNA genotypes and early coronary artery disease. Nitric Oxide Biol. Chem. 2001, 5, 343-348. [CrossRef] [PubMed]

14. Ramachandran, V.; Ismail, P.; Stanslas, J.; Shamsudin, N.; Moin, S.; Mohd Jas, R. Association of insertion/deletion polymorphism of angiotensin-converting enzyme gene with essential hypertension and type 2 diabetes mellitus in malaysian subjects. J. Renin-Angiotensin-Aldost. Syst. JRAAS 2008, 9, 208-214. [CrossRef] [PubMed]

15. Xu, G.; Fan, G.; Sun, Y.; Yu, L.; Wu, S.; Niu, W. Association of angiotensin-converting enzyme gene i/d polymorphism with chronic obstructive pulmonary disease: A meta-analysis. J. Renin-Angiotensin-Aldost. Syst. JRAAS 2018, 19, 1470320318770546. [CrossRef] [PubMed]

16. Mlak, R.; Homa-Mlak, I.; Powrozek, T.; Mackiewicz, B.; Michnar, M.; Krawczyk, P.; Dziedzic, M.; Rubinsztajn, R.; Chazan, R.; Milanowski, J.; et al. Impact of i/d polymorphism of ace gene on risk of development and course of chronic obstructive pulmonary disease. Arch. Med. Sci. AMS 2016, 12, 279-287. [CrossRef] [PubMed]

17. Bautista, L.E.; Ardila, M.E.; Gamarra, G.; Vargas, C.I.; Arenas, I.A. Angiotensin-converting enzyme gene polymorphism and risk of myocardial infarction in colombia. Med. Sci. Monit. 2004, 10, CR473-CR479. [PubMed] 
18. Bahramali, E.; Rajabi, M.; Jamshidi, J.; Mousavi, S.M.; Zarghami, M.; Manafi, A.; Firouzabadi, N. Association of ace gene d polymorphism with left ventricular hypertrophy in patients with diastolic heart failure: A case-control study. BMJ Open 2016, 6, e010282. [CrossRef] [PubMed]

19. Abraham, W.T.; Raynolds, M.V.; Badesch, D.B.; Wynne, K.M.; Groves, B.M.; Roden, R.L.; Robertson, A.D.; Lowes, B.D.; Zisman, L.S.; Voelkel, N.F.; et al. Angiotensin-converting enzyme dd genotype in patients with primary pulmonary hypertension: Increased frequency and association with preserved haemodynamics. J. Renin-Angiotensin-Aldost. Syst. JRAAS 2003, 4, 27-30. [CrossRef] [PubMed]

20. Eddahibi, S.; Humbert, M.; Fadel, E.; Raffestin, B.; Darmon, M.; Capron, F.; Simonneau, G.; Dartevelle, P.; Hamon, M.; Adnot, S. Serotonin transporter overexpression is responsible for pulmonary artery smooth muscle hyperplasia in primary pulmonary hypertension. J. Clin. Investig. 2001, 108, 1141-1150. [CrossRef] [PubMed]

21. Guignabert, C.; Izikki, M.; Tu, L.I.; Li, Z.; Zadigue, P.; Barlier-Mur, A.M.; Hanoun, N.; Rodman, D.; Hamon, M.; Adnot, S.; et al. Transgenic mice overexpressing the 5-hydroxytryptamine transporter gene in smooth muscle develop pulmonary hypertension. Circ. Res. 2006, 98, 1323-1330. [CrossRef] [PubMed]

22. Willers, E.D.; Newman, J.H.; Loyd, J.E.; Robbins, I.M.; Wheeler, L.A.; Prince, M.A.; Stanton, K.C.; Cogan, J.A.; Runo, J.R.; Byrne, D.; et al. Serotonin transporter polymorphisms in familial and idiopathic pulmonary arterial hypertension. Am. J. Respir. Crit. Care Med. 2006, 173, 798-802. [CrossRef] [PubMed]

23. Machado, R.D.; Koehler, R.; Glissmeyer, E.; Veal, C.; Suntharalingam, J.; Kim, M.; Carlquist, J.; Town, M.; Elliott, C.G.; Hoeper, M.; et al. Genetic association of the serotonin transporter in pulmonary arterial hypertension. Am. J. Respir. Crit. Care Med. 2006, 173, 793-797. [CrossRef] [PubMed]

24. Ulasli, S.S.; Eyuboglu, F.O.; Verdi, H.; Atac, F.B. Associations between endothelial nitric oxide synthase A/B, angiotensin converting enzyme I/D and serotonin transporter L/S gene polymorphisms with pulmonary hypertension in COPD patients. Mol. Biol. Rep. 2013, 40, 5625-5633. [CrossRef] [PubMed]

25. Yildiz, P.; Oflaz, H.; Cine, N.; Erginel-Unaltuna, N.; Erzengin, F.; Yilmaz, V. Gene polymorphisms of endothelial nitric oxide synthase enzyme associated with pulmonary hypertension in patients with copd. Respir. Med. 2003, 97, 1282-1288. [CrossRef] [PubMed]

26. Ahsan, A.; Ram, R.; Baig, M.A.; Pasha, M.A. Ace i allele and enos g allele crosstalk may have a role in chronic obstructive pulmonary disease. Clin. Biochem. 2004, 37, 1037-1040. [CrossRef] [PubMed]

27. Hoeper, M.M.; Tacacs, A.; Stellmacher, U.; Lichtinghagen, R. Lack of association between angiotensin converting enzyme (ace) genotype, serum ace activity, and haemodynamics in patients with primary pulmonary hypertension. Heart 2003, 89, 445-446. [CrossRef] [PubMed]

28. Togănel, R.; Muntean, I.; Duicu, C.; Făgărăşan, A.; Gozar, L.; Bănescu, C. The role of enos and agt gene polymorphisms in secondary pulmonary arterial hypertension in romanian children with congenital heart disease. Rom. J. Lab. Med. 2013, 21, 267. [CrossRef]

29. Wang, Y.; Kikuchi, S.; Suzuki, H.; Nagase, S.; Koyama, A. Endothelial nitric oxide synthase gene polymorphism in intron 4 affects the progression of renal failure in non-diabetic renal diseases. Nephrol. Dial. Transplant. 1999, 14, 2898-2902. [CrossRef] [PubMed]

30. Tkacova, R.; Joppa, P.; Stancak, B.; Salagovic, J.; Misikova, S.; Kalina, I. The link between angiotensin-converting enzyme genotype and pulmonary artery pressure in patients with copd. Wiener Klinische Wochenschrift 2005, 117, 210-214. [CrossRef] [PubMed]

31. Togănel, R.; Bănescu, C.; Duicu, C.; Şuteu, C.; Muntean, I.; Făgărăşan, A.; Gozar, L.; Pasc, S. Angiotensin-converting enzyme gene polymorphisms in pulmonary arterial hypertension in children. Revista Română Medicină Lab. 2010, 18, 31.

32. Shafiee, S.M.; Firoozrai, M.; Salimi, S.; Zand, H.; Hesabi, B.; Mohebbi, A. Angiotensin converting enzyme dd genotype not associated with increased risk of coronary artery disease in the iranian population. Pathophysiology 2010, 17, 163-167. [CrossRef] [PubMed]

33. Srivastava, K.; Narang, R.; Sreenivas, V.; Das, S.; Das, N. Association of enos glu298asp gene polymorphism with essential hypertension in asian indians. Clin. Chim. Acta 2008, 387, 80-83. [CrossRef] [PubMed]

34. Ulrich, S.; Hersberger, M.; Fischler, M.; Nussbaumer-Ochsner, Y.; Treder, U.; Russi, E.W.; Speich, R. Genetic polymorphisms of the serotonin transporter, but not the 2a receptor or nitric oxide synthetase, are associated with pulmonary hypertension in chronic obstructive pulmonary disease. Respir. Int. Rev. Thorac. Dis. 2010, 79, 288-295. [CrossRef] [PubMed] 
35. Vasudevan, R.; Ismail, P.; Jaafar, N.; Mohamad, N.; Etemad, E.; WS, W.A.; Eshkor, S. Analysis of human bradykinin receptor gene and endothelial nitric oxide synthase gene polymorphisms in end-stage renal disease among malaysians. Balkan J. Med. Genet. 2014, 17, 37-40. [PubMed]

36. Baloira, A.; Nunez, M.; Cifrian, J.; Vilarino, C.; Ojeda, M.; Valverde, D. Polymorphisms in the serotonin transporter protein (sert) gene in patients with pulmonary arterial hypertension. Arch. Bronconeumol. 2012, 48, 77-80. [CrossRef] [PubMed]

37. Cao, H.; Gu, H.; Qiu, W.; Zuo, W.; Zheng, L.; Wang, Z.; Hu, Z.; Chen, Y. Association study of serotonin transporter gene polymorphisms and ventricular septal defects related possible pulmonary arterial hypertension in chinese population. Clin. Exp. Hypertens. 2009, 31, 605-614. [CrossRef] [PubMed]

2018 by the authors. Licensee MDPI, Basel, Switzerland. This article is an open access article distributed under the terms and conditions of the Creative Commons Attribution (CC BY) license (http://creativecommons.org/licenses/by/4.0/). 